\title{
EHMTI-0121. The disturbances of reactivity of cerebral vessels in patients with posttraumatic headaches
}

\author{
I lakubenko*, T Litovchenko, O Zavalna \\ From 4th European Headache and Migraine Trust International Congress: EHMTIC 2014 \\ Copenhagen, Denmark. 18-21 September 2014
}

Microstructural disturbances develop in the wall of vessels in patients with mild traumatic brain injuries (TBI).

The purpose of our research was to detect the regularities of changes of hemodynamics and reactivity of cerebral circulation in patients with consequences of mild traumatic brain injuries by using the method of Doppler ultrasonography with hyper-and hypocapnic tests.

\section{Materials and methods}

We examined 62 patients with consequences of mild TBI. The control group consisted of 20 healthy people. Doppler ultrasonography with hyper-and hypocapnic tests were carried out according to the standard method.

\section{Results}

Conducting Doppler ultrasonography with hyper-and hypocapnic tests in the patients with consequences of TBI we detected that coefficient of reactivity was $1.11 \pm 0.07$. The insignificant asymmetry of bloodflow which increased after hyper- and hypocapnia was observed in the patients (82\%). An early development of atherosclerotic lesion of cerebral vessels in the form of hemodynamic insignificant atherosclerotic plaques of the walls of cerebral vessels was observed (73\%). We detected paradoxical reaction of cerebral vessels in 40 patients when hyper-and hypocapnic tests were being held.

\section{Conclusions}

The data obtained confirm the changes of reactivity of cerebral vessels towards the decrease of linear velocity of bloodflow in the patients with consequences of mild TBA. The detected paradoxical reaction of vessels which was

Neurology, Kharkov Medical Academy of Postgraduate Education, Kharkov, Ukraine

\section{SpringerOpen ${ }^{\circ}$}

observed when we used hyper-and hypocapnic tests, is the consequence of the decrease of elasticity of vessels walls as a result of microstructural disturbances of vessels, an early development of atherosclerotic changes in vessels and the manifestation of a long-term angiospasm.

No conflict of interest.

Published: 18 September 2014

doi:10.1186/1129-2377-15-S1-C23

Cite this article as: lakubenko et al:: EHMTI-0121. The disturbances of reactivity of cerebral vessels in patients with posttraumatic headaches. The Journal of Headache and Pain 2014 15(Suppl 1):C23.
Submit your manuscript to a SpringerOpen ${ }^{\circ}$ journal and benefit from:

$\checkmark$ Convenient online submission

- Rigorous peer review

- Immediate publication on acceptance

- Open access: articles freely available online

- High visibility within the field

- Retaining the copyright to your article

Submit your next manuscript at $\boldsymbol{~ s p r i n g e r o p e n . c o m ~}$ 